\title{
THE EFFECT OF INDONESIAN MACROECONOMIC CONDITION AND INTERNATIONAL INTEREST RATE ON YIELD OF THE GOVERNMENT BOND IN US DOLLAR
}

\author{
Farouq Widya Pramana* \\ Ministry of Finance, Republic of Indonesia \\ Nachrowi D. Nachrowi \\ Faculty of Economics, University of Indonesia
}

\begin{abstract}
This study analyzes the effect of Indonesian macroeconomic condition and international interest rate shocks on yield of the Government Bond in US Dollar. This study applies Vector Error Correction Model (VECM) using monthly data which consists of yield of the Government Bond in US Dollar, domestic interest rate, price level, real exchange rate, and international interest rate during the period of January 2006 to December 2013. The results show that domestic interest rate, price level, real exchange rate, and international interest rate have significant positive impacts on yield of the Government Bond in US Dollar and confirm the presence of the error correction mechanism in the yield of the Government Bond in US Dollar model that also indicates the existence of cointegration.
\end{abstract}

Keywords: Yield; Cointegration; Macroeconomic condition; Vector Error Correction Model

\section{JEL Classifications: F34, G15}

\section{INTRODUCTION}

Bond as one of the instruments in the financial market becomes an alternative that can be used by either the government or private sectors to post or collect funds in the market. By considering the budget deficit and the dynamics of both global and domestic financial markets, government commits to diversify the debt portfolio by issuing the government bond in domestic and international markets with both Rupiah denomination and foreign currency. Beside financing source of budget deficit, government bond can also serve as a benchmark for financial market agents.

The government bond in US Dollar can be traded in the secondary market based on the price rates and yields developed in the market. According to Min et al (2003),

\footnotetext{
*Corresponding e-mail: didit.bagus@gmail.com
} 
bond yield in US dollar issued by the government in developing countries fluctuatively affected by domestic economy and international interest rates. The high inflation that indicates the unstable macroeconomic condition can explain the low demand in both domestic and foreign currency bonds (Claessens et al. 2003). The influence variation between domestic economic condition and international interest rates can also be an important consideration for the government in achieving the target of optimum debt portfolio structure. Based on Joutz et al. (2002), it is stated that bond issued with a status of non-investment grade is more vulnerable to be shocked from the external factors. With the market capitalization rate and dominant turnover compared to other countries, the United States has a major influence toward global financial market including bond market (Bayoumi et al, 2012). The condition of economy in the US as reflected in the yield of US Treasury Bills is predicted to provide significant contribution to the yield of the Government Bond in US Dolar. The US Treasury Bills yield as the proxy of the international interest rate can also describe the external influence on bond yield of US Dollar in developing countries (Bunda et al, 2009).

The initial indication of co-movement between yield of the Government Bond in US Dollar and the economic condition can occur through the process of correction or deviation of the yield of Government Bond in US Dollar from the long-term equilibrium. There have been much studies regarding international bond published by other countries by employing various models and resulting in various findings. Budina et al (2000), for example, with the VECM model proves the existence of cointegration between the price of Bulgarian Brady Bonds and both domestic and external economic condition. Min et al. (2003) provides evidence that inflation, real exchange rate, and international interest rate have a positive effect on bond yield spread in US Dollar in Latin America. The studies concerning bond yield issued by Indonesian Government conducted by Tampubolon (2007) and Adli (2013) show the role of short-term interest rate in the development of bond yield as the longterm interest rate. Furthermore, Jacobs et al. (2011) with the panel data model demonstrates the influence of fundamental and external factors on yield spread of Indonesia foreign exchange bond and peer countries.

The number of studies dealing with international bond published by Indonesian Government is very limited. The main difference between this study and some previous 
studies on the government bond yield is the use of dynamic analysis model and the international interest rate variable to focus as the external factor effect. So, this study is expected to be more relevant in describing the dynamics of financial markets in the country. This study specifically is aimed at constructing the dynamic model of government bond yield in US Dollar which takes into account the exogenous international interest rate with the indication of cointegration, and analyzing response as well as domination of economic condition on the government bond yield in US Dollar. Indonesian macroeconomic variable in this case includes domestic interest rate, price rate, and real exchange rate. What is interesting from this study is that we are looking at the long-term relationship in the model of government bond yield in US Dollar and different response pattern in the government bond yield in US Dollar with 10 year tenor and 30 year effects of economic shock.

This study consists of five sections. The first is introduction which consists of background of study, research questions and objectives of study. The second section includes literature review which describes the underlying theories, empirical result, and some hypothesis. The third section described the research methods comprising data and analysis method. The fourth section explains the result and discussion. The final part consists of conclusion and recommendation for improving similar research in the following period.

\section{LITERATURE REVIEW}

Bond price is the discount value of payment coupon until the date of maturity including the bond principal value at certain interest rate. In the case of increasing interest rate, the bond price will decrease according to the present value of the bond with a higher discount rate (Bodie et al 2003). The equation of bond price is as follow:

$$
\mathrm{P}=\sum_{\mathrm{t}=1}^{\mathrm{T}} \frac{\text { Coupon }}{(1+\mathrm{r})^{\mathrm{t}}}+\frac{\text { ParValue }}{(1+\mathrm{r})^{\mathrm{T}}}
$$

where $\mathrm{P}$ is bond price, $\mathrm{r}$ is Yield to Maturity (YTM), $\mathrm{t}$ is current period of time, and $\mathrm{T}$ is maturity term.

By assuming that investors are risk neutral, the increasing yield of US Treasury Bills as risk-free interest rate instrument will lead to the increasing yield of the other more risky bonds. It illustrates investors' escalating risk perception which encourages 
bond selling and will result in declining bond price and rising yield. Bond demand in the international market is not only influenced by macroeconomic condition but also influenced by risk preference of global investor (Claudia-Floriana, 2008).

Yield on government bond in US Dollar has similar characteristics to interest rate as discount factor in determining present value of total income. The Expectation Hypothesis of the Term Structure of Interest Rates theory explains the relationship between return rates of various bonds with different maturity dates (Griffin, 2002). In the case of the prevailing hypothesis, long-term interest rate is a reflection of short-term interest rate expectation. Fama (1984) proved that the expected return of long-term bond is bigger than that of short term bond, and the increasing expected return is not monotonic to bond maturity date.

The relationship between domestic interest rate, foreign interest rate, and exchange rate can be explained by means of interest rate parity design. This design is expected to be able to interpret the movement of government bond yield in US Dollar through interaction existing simultaneously with domestic interest rate and exchange rate. In the economic framework, the relationship developed in the concept of interest rate parity basically has interconnection with other variables which also affect domestic interest rate, foreign interest rate, and exchange rate. By using purchasing power parity design which describes the relationship between price rate and exchange rate, it is expected to be able to explain the interconnection between price rate and domestic interest rate or government bond yield in US Dollar. Purchasing power parity design predicts that real exchange rate will have the value of one (balance value) or will soon be one if the long-term ratio between domestic and foreign price is interrupted (Obstfeld dan Rogoff, 1996).

The role of monetary policy is important in influencing the condition of financial markets. Central Bank's main concept of policy rule which is commonly known consists of monetary growth rule and interest rate rule (Juhro, S., 2008). A very quick market dynamic and along with displacement in universal monetary regime policy from what used to be money base into interest rate base with Inflation Targeting Framework, makes Taylor Rule approach more relevant to explain the transmission of monetary 
policy and macroeconomic condition in affecting financial market including bond market by means of short-term interest rate way.

The study on bond in international market in practice cannot be separated from the effect of international economy considering the more transparent and integrated condition of global financial market. Budina et al. (2000) studied factors influencing price in two types of Brady Bonds in US Dollar issued by Bulgaria with monthly data from the period of Juli 1994 until Juli 1998 using ECM and VECM methods. Based on ECM approach, it can be concluded that export, exchange reserve, and dummy domestic condition positively affect bond price, while real exchange rate, dummy Asian crisis, and Mexican Exchange currency rate negatively influence bond price. Meanwhile, using VECM approach, restriction model is added where economic fundamental is weakly exogenous toward bond price with the presence of cointegration between bond price and economic condition.

Min et al. (2003) conducted study with pooled data of developing countries in the period between 1991 and 1999 to see factors influencing yield to bond spread in US Dollar. The empirical result showed that the effect of real exchange rate on yield spread is in line with findings by Budina et al. (2000), whereas Mexican currency crisis does not significantly affect yield spread which is probably caused by the low trend of interest rates due to global economic optimism in the early 1995.

Jacobs et al. (2011) studied spread of bond yield in US Dollar published by Indonesian Government and peer countries with panel data regression. The results indicated that volatility index (VIX) positively influences bond yield corresponds with findings by Budina et al. (2000), where the worsening condition of external factors will increase the bond yield. It is predicted that the increasing real exchange value which decreases bond yield index is due to the relatively much lower position of real exchange rate of countries in the region compared to parity condition. At the same time, inflation has a positive effect on bond yield as stated by Min et al. (2003).

Study by Audzeyeva et al. (2010) on daily yield data zero-coupon Eurobonds of Latin American countries and zero coupon bond of the US Government in the period from 2003 to 2009 demonstrated that economic factor and global crisis have a major impact on bond yield. The influence of the US' bonds to other countries' bonds is verified 
by Jeon et al. (2012), Bredin et al. (2010), and Bayoumi et al. (2012) with a conclusion that leads to the significant influence of the US Bond in the global financial market.

The role of short-term interest rate in developing long-term rate structure is shown in the studies conducted by Tampubolon (2007) and Adli (2013). Both studies used VAR and VECM models with the assumption that the existing theories were too complicated to explain the specification of dynamic structure of bond yield. The result specifically showed that interest rate has a positive influence on the government bond yield which indicates the role of short-term interest rate in forming the long-term interest rate structure.

This study refers to the model constructed by Budina et al. (2000) with some variable modification and consideration of exogenous international interest rate. Based on the economic theories and empirical review, it is predicted that the international interest rate, real exchange rate, domestic interest rate, and price rate have a positive influence on the government bond yield in US Dollar in Indonesia.

\section{RESEARCH METHODS}

This study uses secondary data. The Government bond yield in US Dollar (YRI) is obtained from the Ministry of Finance (Bloomberg), while the international interest rate (YUS) with the yield proxy of US Treasury Bills with 6 month tenor is obtained from the US Department of the Treasury. Real exchange rate (RER) with the proxy of real effective exchange rate index is obtained from Bank for International Settlement, while domestic interest rate $(\mathrm{R})$ in percentage with an interest rate proxy of Inter-Banks Financial Market is obtained from Bank of Indonesia, and price rate (P) with the proxy of Consumer Price Index is obtained from Central Statistical Board (BPS). This study is conducted toward the Government Bond Yield in US Dollar in the secondary market, i.e. series RI0016 and RI0035 maturing in 10 years (YRI10) and 30 years (YRI30) respectively and the study period between January 2006 and December 2013.

The descriptive analysis shows that the average value of YRI30 is higher than that of YRI10 according to the development of interest rate structure where the longer the maturity is, the higher the yield will be. Meanwhile, YUS has the lowest average 
compared to variable R or YRI, indicating the low perception of financial market agents on investment instrument in the United States.

Figure 1. Data Spread for all Variables

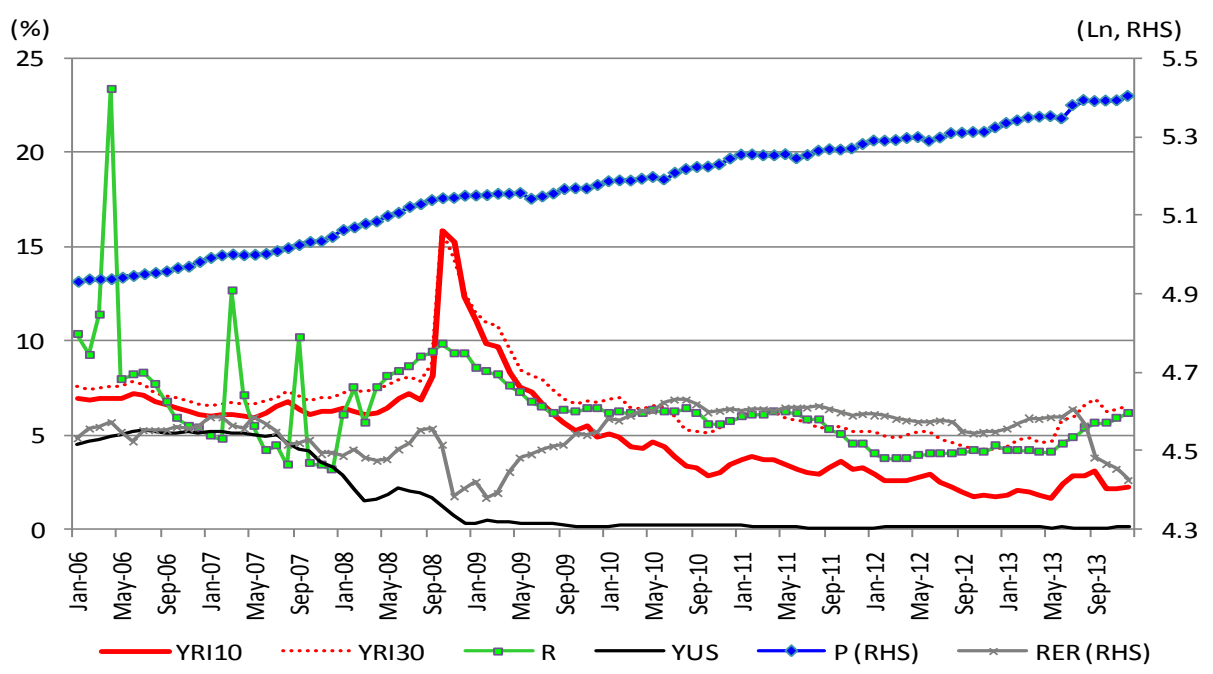

Source: Authors' Calculations

In the study with time series data, the use of Ordinary Least Square (OLS) estimation has a potential to result in spurious regression. Generally, time series data is non-stationary and if the value of $\mathrm{R}^{2}$ is high whereas there are many insignificant variables, spurious regression is predicted to occur (Gujarati, 2003). According to the economic theory requiring long-term balance and considering the trend of intervariables data especially during the initial Global Financial Crisis of 2008, cointegration mechanism analysis will be applied on the model of the Government Bond Yield in US Dollar.

The limitation of the economic theory in explaining bond yield model in foreign currency leads the study to the use of VECM model. Restriction adding on the equation set of international interest rate is indispensable to demonstrate the exogenous nature of international interest rate and will determine the transmission pattern among variables. Based on this fact and the research objective, the model used in this study is as follows: 


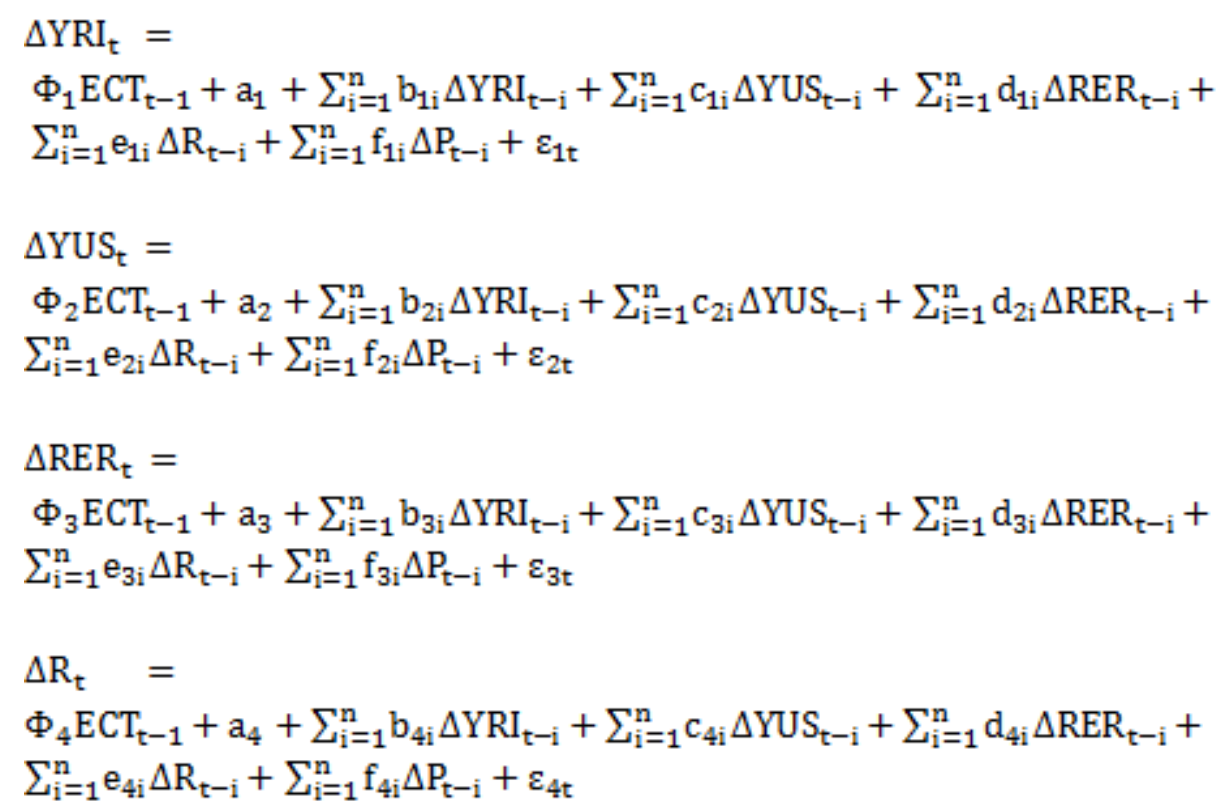

where:

$$
\begin{aligned}
\mathrm{ECT}_{\mathrm{t}-1} & =\left[\mathrm{YRI}_{\mathrm{t}-1}+\beta_{1} \mathrm{YUS}_{\mathrm{t}-1}+\beta_{2} \mathrm{RER}_{\mathrm{t}-1}+\beta_{3} \mathrm{R}_{\mathrm{t}-1}+\beta_{4} \mathrm{P}_{\mathrm{t}-1}\right] \\
\Phi_{2} & =0
\end{aligned}
$$

with $\Phi i$ is coefficient of Error Correction Term (ECT), a $a_{i}$ is constant, $b_{j i}, c_{j i}, d_{j i}, e_{j i}, f_{j i}$ is regression coefficient, $\varepsilon_{i t}$ is error term, $\beta$ is cointegration equation coefficient, and $\Delta$ is lag operation.

The long-term relationship among variables is an equilibrium condition throughout the study period developed through the correction mechanism represented by negative coefficient of ECT. According to Harbo et.al (1998), in the case of cointegration equation model, when there is an equation set of a variable which has no ECT (zero valued), the concerned variable will not react if there is a deviation from the long-term equilibrium illustrated in the cointegration equation. In this study, the econometrics analysis process uses the Eviews7 software.

The testing of stationarity data employs the technique of Augmented DickeyFuller (ADF). In the mean time, lag determination is a very important stage in the VECM analysis model since it will describe the dynamic influence of exogenous variable lag toward endogenous variable. Optimum lag is determined by using Akaike Information Criterion (AIC) method. In this study, cointegration testing Johansen Cointegration Test 
method developed using rank and matrix characteristic root as multivariate generalization on Dickey-Fuller test (Enders, 1995).

With weakly exogenous assumption, equation set of $\triangle \mathrm{YUS}_{\mathrm{t}}$ in VECM model will be restricted, so that ECT coefficient in the equation is zero valued $\left(\Phi_{2}=0\right)$. On the basis of research objectives and limitations which focus on the effect of Indonesia macroeconomic condition and international interest rate on The Government Bond Yield in US Dollar, VECM model will apply one cointegration equation. Estimation of VECM model will result in cointegration coefficient in the same manner as equation above; therefore, the formed long-term equation is as the following:

$$
\mathrm{YRI}_{\mathrm{t}}=\beta_{1} \mathrm{YUS}_{\mathrm{t}}+\beta_{2} \mathrm{RER}_{\mathrm{t}}+\beta_{3} \mathrm{R}_{\mathrm{t}}+\beta_{4} \mathrm{P}_{\mathrm{t}}+\mathrm{e}_{\mathrm{t}}
$$

where $\beta_{\mathrm{i}}$ is economic variable coefficient and $\mathrm{e}_{\mathrm{t}}$ is error term.

To measure the quantity of Indonesia macroeconomic condition effect and international interest rate on The Government Bond Yield in US Dollar, the impulse response function and variance decomposition analyses are implemented. By considering the characteristics of international interest rate and monetary policy transmission, the ordering for impulse response function analysis is: YUS $\rightarrow \mathbf{R E R} \rightarrow \mathbf{R} \rightarrow$ $\mathbf{P} \rightarrow$ YRI. The analysis is limited to 12 study periods as the study aims at finding out the difference in the response pattern of the Government Bond Yield in US Dollar toward shock of each economic condition, thus it can focus more on observing the speed and quantity of significant effect until the effect of the shock is reduced.

\section{FINDINGS AND DISCUSSION}

The stationarity testing process uses the ADF method with intercept and trend. ADF test on each research variable data shows that data at the Level stage is not stationary whereas data at the First Difference stage is stationary (see table 1).

Table 1. Result of Stationarity Test at the First Difference stage

\begin{tabular}{|l|c|c|c|c|}
\hline No. & Variable & t-test ADF & $\begin{array}{c}\boldsymbol{t} \text {-stat ADF } \\
(\boldsymbol{\alpha = 5 \% )}\end{array}$ & Description \\
\hline 1. & YRI10 & -7.866540 & -3.458856 & Stationary \\
\hline 2. & YRI30 & -8.754734 & -3.458326 & Stationary \\
\hline 3. & YUS & -5.271295 & -3.458326 & Stationary \\
\hline
\end{tabular}




\begin{tabular}{|l|c|c|c|c|}
\hline 4. & RER & -7.700343 & -3.458326 & Stationary \\
\hline 5. & $\mathrm{R}$ & -3.764063 & -3.464198 & Stationary \\
\hline 6. & $\mathrm{P}$ & -9.179956 & -3.458326 & Stationary \\
\hline
\end{tabular}

Source: Authors' Calculations

Finding the length of lag in the VECM model analysis is very crucial as it will influence the analysis result of Impulse Response Function and Variance Decomposition. As in the analysis process, the length of lag has the function to measure the responsiveness of each variable on the endogenous variable. The result of optimum lag finding on the equation model of YRI10 and YRI30 refers to the smallest value of AIC which results in lag 3 by taking into account the degree of freedom.

Cointegration testing outcome indicates that both YRI equation models have two cointegration equations and shows the existence of long-term relationship in the equation system. To come up with the best model, this study employs linear trend assumption on the data and cointegration equation with intercept. The estimation result using these two alternatives of cointegration vectors indicate the presence of correction mechanism represented by negative and significant value of ECT coefficient on both models of the government bond yield in US Dollar. Nevertheless, the use of two cointegration vectors in the VECM model tends to result in inconsistent value for both ECT coefficient and regression coefficient based on a different iteration process. Meanwhile, the use of one cointegration vector has consistently been able to describe the effect of Indonesia macroeconomic variable and international interest rate on the yield of Government Bond in US Dollar and it is simpler compared to the model using two cointegration vectors.

Next, the VECM model formation in this study is conducted independently for YRI10 and YRI30 on the change influence of variables YUS, RER, R and P by adding zero restriction to the equation set of international interest rate (YUS). With this restriction adding, it can be interpreted that the deviation of the yield on the government bond in US Dollar from the long-term balance will not influence the dynamics of international interest rates. The testing of LR Test on both YRI equation models proves that the hypothesis of zero restriction adding is not denied; thus, it can be concluded that 
restriction adding in the VECM model is valid and can be analysed further. Data processing with VECM model will lead to two types of equation, i.e. short-term equation represented lag operation $(\Delta)$ of each variable and long-term equation represented by Error Correction Term (ECT). The analysis result of each YRI10 and YRI30 is as follows:

(1) Model of yield on the Government Bond in US Dollar maturing in 10 years:

$$
\begin{aligned}
& {\left[\begin{array}{c}
\Delta \mathrm{YRI}^{\mathrm{N} 10_{\mathrm{t}}} \\
\Delta \mathrm{YUS}_{\mathrm{t}} \\
\Delta \mathrm{RER}_{\mathrm{t}} \\
\Delta \mathrm{R}_{\mathrm{t}} \\
\Delta \mathrm{P}_{\mathrm{t}}
\end{array}\right]=\left[\begin{array}{c}
-0,02 \\
0 \\
0,0004 \\
0,06 \\
2 \mathrm{E}-05
\end{array}\right]\left[\begin{array}{llll}
1-12,98-159,72-11,78-245,29 & 2083,71
\end{array}\right]\left[\begin{array}{c}
\mathrm{YRI}^{2} 0_{\mathrm{t}-1} \\
\mathrm{YUS}_{\mathrm{t}-1} \\
\mathrm{RER}_{\mathrm{t}-1} \\
\mathrm{R}_{\mathrm{t}-1} \\
\mathrm{P}_{\mathrm{t}-1} \\
1
\end{array}\right]+} \\
& {\left[\begin{array}{ccc}
0,09 & -0,19 & -0,02 \\
-0,04 & -0,04 & 0,03 \\
-0,01 & 0,007 & -0,005 \\
0,28 & 0,05 & 0,36 \\
0,001 & 0,0006 & -0,0005
\end{array}\right]\left[\begin{array}{ccc}
\Delta \mathrm{YRI}_{10} 0_{\mathrm{t}-1} \\
\Delta \mathrm{YRI}_{\mathrm{t}-2} \\
\Delta \mathrm{YRI} 10_{\mathrm{t}-\mathrm{a}}
\end{array}\right]+\left[\begin{array}{ccc}
-1,42 & 0,96 & -1,93 \\
0,54 & -0,08 & 0,04 \\
-0,003 & 0,04 & -3 \mathrm{E}-05 \\
0,52 & 2,93 & 0,2 \\
-0,003 & 0,006 & -0,008
\end{array}\right]\left[\begin{array}{l}
\Delta \mathrm{YUS}_{\mathrm{t}-1} \\
\Delta \mathrm{YUS}_{\mathrm{t}-2} \\
\Delta \mathrm{YUS}_{\mathrm{t}-\mathrm{a}}
\end{array}\right]+} \\
& {\left[\begin{array}{ccc}
10,51 & 5,33 & 7,22 \\
-0,82 & 0,35 & 0,1 \\
0,32 & -0,21 & 0,16 \\
-7,63 & 7,86 & -10,17 \\
0,03 & -0,01 & -0,02
\end{array}\right]\left[\begin{array}{l}
\Delta \mathrm{RER}_{\mathrm{t}-1} \\
\Delta \mathrm{RER}_{\mathrm{t}-2} \\
\Delta \mathrm{RER}_{\mathrm{t}-\mathrm{a}}
\end{array}\right]+\left[\begin{array}{ccc}
-0,18 & -0,1 & -0,06 \\
-0,003 & -0,005 & 0,008 \\
0,002 & 0,0006 & 0,001 \\
-0,18 & -0,09 & -0,08 \\
0,0002 & 0,0004 & 8 \mathrm{E}-05
\end{array}\right]\left[\begin{array}{l}
\Delta \mathrm{R}_{\mathrm{t}-1} \\
\Delta \mathrm{R}_{\mathrm{t}-2} \\
\Delta \mathrm{R}_{\mathrm{t}-\mathrm{a}}
\end{array}\right]+} \\
& {\left[\begin{array}{ccc}
14,68 & 14,53 & 9,98 \\
-0,13 & -1,16 & -0,09 \\
-0,2 & -0,15 & 0,25 \\
45,07 & 38,07 & 24,05 \\
-0,03 & -0,24 & -0,15
\end{array}\right]\left[\begin{array}{l}
\Delta \mathrm{P}_{\mathrm{t}-1} \\
\Delta \mathrm{P}_{\mathrm{t}-2} \\
\Delta \mathrm{P}_{\mathrm{t}-\mathrm{a}}
\end{array}\right]+\left[\begin{array}{c}
-0,36 \\
-0,02 \\
0,0008 \\
-0,52 \\
0,007
\end{array}\right]}
\end{aligned}
$$

Based on equation (4), the short-term and long-term equations of YRI10 variable are:

$$
\begin{aligned}
\Delta \mathrm{YRI}_{\mathrm{t}}= & -0,02 \mathrm{ECT}_{\mathrm{t}-1}+0,09 \Delta \mathrm{YRI}_{\mathrm{t}-1}-0,19 \Delta \mathrm{YRI}_{\mathrm{t}-2}-0,02 \Delta \mathrm{YRI}_{\mathrm{t}} 0_{\mathrm{t}-\mathrm{a}} \\
& -1,42 \Delta \mathrm{YUS}_{\mathrm{t}-1}+0,96 \Delta \mathrm{YUS}_{\mathrm{t}-2}-1,93 \Delta \mathrm{YUS}_{\mathrm{t}-\mathrm{a}}+10,51 \Delta \mathrm{RER}_{\mathrm{t}-1} \\
& +5,33 \Delta \mathrm{RER}_{\mathrm{t}-2}+7,22 \Delta \mathrm{RER}_{\mathrm{t}-\mathrm{a}}-0,18 \Delta \mathrm{R}_{\mathrm{t}-1}-0,1 \Delta \mathrm{R}_{\mathrm{t}-2}-0,06 \Delta \mathrm{R}_{\mathrm{t}-\mathrm{a}} \\
& +14,68 \Delta \mathrm{P}_{\mathrm{t}-1}+14,53 \Delta \mathrm{P}_{\mathrm{t}-2}+9,98 \Delta \mathrm{P}_{\mathrm{t}-\mathrm{a}}-0,36
\end{aligned}
$$

where:

$$
\begin{aligned}
& \mathrm{ECT}_{\mathrm{t}-1}=\left[\mathrm{YRI}_{10} \mathrm{t}_{\mathrm{t}-1}-12,98 \mathrm{YUS}_{\mathrm{t}-1}-159,72 \mathrm{RER}_{\mathrm{t}-1}-11,78 \mathrm{R}_{\mathrm{t}-1}-\right. \\
& \left.245,29 \mathrm{P}_{\mathrm{t}-1}+2083,71\right]
\end{aligned}
$$

(2) Model of Yield on The Government Bond in US Dollar maturing in 30 years:

$$
\left[\begin{array}{c}
\Delta \mathrm{YRI}^{2} 0_{\mathrm{t}} \\
\Delta \mathrm{YUS}_{\mathrm{t}} \\
\Delta \mathrm{RER}_{\mathrm{t}} \\
\Delta \mathrm{R}_{\mathrm{t}} \\
\Delta \mathrm{P}_{\mathrm{t}}
\end{array}\right]=\left[\begin{array}{c}
-0,07 \\
0 \\
0,001 \\
0,19 \\
6 \mathrm{E}-05
\end{array}\right]\left[\begin{array}{llll}
1-3,75-36,07-3,88-74,47 & 572,55
\end{array}\right]\left[\begin{array}{c}
\mathrm{YRI}^{2} 0_{\mathrm{t}-1} \\
\mathrm{YUS}_{\mathrm{t}-1} \\
\mathrm{RER}_{\mathrm{t}-1} \\
\mathrm{R}_{\mathrm{t}-1} \\
\mathrm{P}_{\mathrm{t}-1} \\
1
\end{array}\right]+
$$




$$
\begin{aligned}
& {\left[\begin{array}{ccc}
-0,01 & -0,17 & -0,06 \\
-0,04 & -0,05 & 0,03 \\
-0,02 & 0,006 & -0,005 \\
0,25 & 0,08 & 0,37 \\
0,002 & 0,001 & -0,0007
\end{array}\right]\left[\begin{array}{l}
\Delta \mathrm{YRI} 30_{\mathrm{t}-1} \\
\Delta \mathrm{YRI} 30_{\mathrm{t}-2} \\
\Delta \mathrm{YRI} 30_{\mathrm{t}-\mathrm{a}}
\end{array}\right]+\left[\begin{array}{ccc}
-1,43 & 0,85 & -1,91 \\
0,55 & -0,09 & 0,03 \\
-0,005 & 0,04 & -0,003 \\
0,63 & 2,9 & 0,24 \\
-0,003 & 0,006 & -0,009
\end{array}\right]\left[\begin{array}{l}
\Delta \mathrm{YUS}_{\mathrm{t}-1} \\
\Delta \mathrm{YUS}_{\mathrm{t}-2} \\
\Delta \mathrm{YUS}_{\mathrm{t}-\mathrm{a}}
\end{array}\right]+} \\
& {\left[\begin{array}{ccc}
7,51 & 5,15 & 5,49 \\
-0,89 & 0,36 & -0,05 \\
0,33 & -0,26 & 0,19 \\
-6,99 & 8,23 & -10,61 \\
0,05 & -0,01 & -0,02
\end{array}\right]\left[\begin{array}{l}
\Delta \mathrm{RER}_{\mathrm{t}-1} \\
\Delta \mathrm{RER}_{\mathrm{t}-2} \\
\Delta \mathrm{RER}_{\mathrm{t}-\mathrm{a}}
\end{array}\right]+\left[\begin{array}{ccc}
-0,18 & -0,1 & -0,06 \\
-0,003 & -0,005 & 0,007 \\
0,002 & 0,0007 & 0,002 \\
-0,14 & -0,06 & -0,07 \\
0,0001 & 0,0004 & 8 \mathrm{E}-05
\end{array}\right]\left[\begin{array}{l}
\Delta \mathrm{R}_{\mathrm{t}-1} \\
\Delta \mathrm{R}_{\mathrm{t}-2} \\
\Delta \mathrm{R}_{\mathrm{t}-\mathrm{a}}
\end{array}\right]+} \\
& {\left[\begin{array}{ccc}
16,53 & 12,4 & 9,89 \\
0,03 & -1,24 & -0,16 \\
-0,21 & -0,11 & 0,22 \\
42,4 & 35,45 & 24,14 \\
-0,05 & -0,25 & -0,15
\end{array}\right]\left[\begin{array}{l}
\Delta \mathrm{P}_{\mathrm{t}-1} \\
\Delta \mathrm{P}_{\mathrm{t}-2} \\
\Delta \mathrm{P}_{\mathrm{t}-\mathrm{a}}
\end{array}\right]+\left[\begin{array}{c}
-0,33 \\
-0,022 \\
0,0009 \\
-0,51 \\
0,007
\end{array}\right]}
\end{aligned}
$$

Based on equation (7), the short-term and long-term equations for YRI30 variable are:

$$
\begin{aligned}
\Delta \mathrm{YRI}^{3} \mathrm{t}_{\mathrm{t}}= & -0,07 \mathrm{ECT}_{\mathrm{t}-1}-0,01 \Delta \mathrm{YRI}^{3} 0_{\mathrm{t}-1}-0,17 \Delta \mathrm{YRI} 0_{\mathrm{t}-2}-0,06 \Delta \mathrm{YRI} 0_{\mathrm{t}-\mathrm{a}} \\
& -1,43 \Delta \mathrm{YUS}_{\mathrm{t}-1}+0,85 \Delta \mathrm{YUS}_{\mathrm{t}-2}-1,91 \Delta \mathrm{YUS}_{\mathrm{t}-\mathrm{a}}+7,51 \Delta \mathrm{RER}_{\mathrm{t}-1} \\
& +5,15 \Delta \mathrm{RER}_{\mathrm{t}-2}+5,49 \Delta \mathrm{RER}_{\mathrm{t}-\mathrm{a}}-0,18 \Delta \mathrm{R}_{\mathrm{t}-1}-0,1 \Delta \mathrm{R}_{\mathrm{t}-2}-0,06 \Delta \mathrm{R}_{\mathrm{t}-\mathrm{a}} \\
& +16,53 \Delta \mathrm{P}_{\mathrm{t}-1}+12,4 \Delta \mathrm{P}_{\mathrm{t}-2}+9,89 \Delta \mathrm{P}_{\mathrm{t}-\mathrm{a}}-0,33
\end{aligned}
$$

where:

$$
\begin{aligned}
& \mathrm{ECT}_{\mathrm{t}-1}=\left[\mathrm{YRI}_{30} 0_{\mathrm{t}-1}-3,75 \mathrm{YUS}_{\mathrm{t}-1}-36,07 \mathrm{RER}_{\mathrm{t}-1}-3,88 \mathrm{R}_{\mathrm{t}-1}-74,47 \mathrm{P}_{\mathrm{t}-1}+\right. \\
& 572,55]
\end{aligned}
$$

Both YRI10 and YRI30 models provides negative and significant value of ECT coefficient at $\alpha=5 \%$, so it can be concluded that there is a correction mechanism on both YRI models. To see the influence of YUS, RER, R, and P variables on YRI10 and YRI30 variables can be estimated by transforming cointegration equation in the same manner as equation (6) and (9) into:

$$
\begin{aligned}
& \mathrm{YRI}_{10}=-2083,71+12,98 \mathrm{YUS}_{\mathrm{t}}+159,72 \mathrm{RER}_{\mathrm{t}}+11,78 \mathrm{R}_{\mathrm{t}}+245,29 \mathrm{P}_{\mathrm{t}}+\mathrm{ECT}_{\mathrm{t}} \\
& \text { and } \\
& \text { YRI } 30_{\mathrm{t}}=-572,55+3,75 \mathrm{YUS}_{\mathrm{t}}+36,07 \mathrm{RER}_{\mathrm{t}}+3,88 \mathrm{R}_{\mathrm{t}}+74,47 \mathrm{P}_{\mathrm{t}}+\mathrm{ECT}_{\mathrm{t}}
\end{aligned}
$$

Based on equation (10) and (11) where all coefficients of cointegration equation are significant at $\alpha=5 \%$, it can be inferred that in general, there is no difference in the direction of YUS, RER, R, and P effect on YRI10 and YRI30. It proves the consistent effect of the change in Indonesia macroeconomic condition and international interest rate on both types of yield on the government bond in US Dollar with different maturity. 
International interest rate has a positive influence on the yield on the government bond in US Dollar which is in line with the hypothesis. The increasing international interest rate indicates the ascending risk level of global investment, so that investor's perception on the risk level of investment instrument issued by emerging market countries such as the government bond in US Dollar will also rise as proposed by Min et al. (2003). Next, this will drive investors to move their portfolios to low-risk assets like the US Treasury Bills which will cause the price of the government bond in US Dollar affected and the yield will rise.

Real exchange rate has a positive influence on the yield of the government bond in US Dollar which is also in line with the research hypothesis. This is in accordance with findings by Budina et al. (2000) where real exchange rate negatively affects the price of Brady Bonds or positively affects its yield. Real exchange rate based on the purchasing power parity framework shows the level of a country's economic competitiveness. The higher the real exchange rate, the lower the economic competitivenss will be. Besides, it also reflects the weakening purchasing power of domestic currency relative to foreign products. The keep increasing real exchange rate exceeding its balance value will make Rupiah currency lose its competitiveness compared to other countries' currencies, thus raising the risk to hold currency and asset portfolio in Rupiah denomination. This condition will result in the foreign capital outflow which can disturb the stability of exchange rate and can lead to the increasing yield of the government bond in US Dollar.

Domestic interest rate has a positive influence on the yield of the government Bond in US Dollar as the hypothesis. With the assumption that the exchange rate is stable, the positive influence of domestic interest rate on the yield of the Government Bond in US Dollar can illustrate the mechanism of interest rate change as the interest rate parity framework. Based on The Expectation Hypothesis of the Term Structure of Interest Rates, domestic interest rate with characteristic of short-term interest rate will affect the formation process of the yield structure with the characteristic of long-term interest rate. Therefore, the increasing of short-term interest rate will lead to the society expectation on the rising of long-term interest rate.

Moreover, price rate has a positive influence toward the yield of the Government Bond in US Dollar which is consistent with the research hypothesis. In line with Taylor Rule mechanism that the increasing gap between expectation and inflation realization 
will cause the rising short-term interest rate. Therefore, this result can consistently explain the positive influence of price rate on both short-term and long-term interest rates. Bank of Indonesia in maintaining inflation rate may make use of short-term interest rate instrument as the operational target. In the case of rising inflation, Bank of Indonesia (BI) will adjust BI rate by making it higher so that it is expected to be able to encourage higher short-term interest rate to keep down the inflation rate. Uncontrolled inflation potentially brings a negative effect on output. One of the indicators used by market agents to measure the ability of a country to pay its debt is the debt to GDP (Gross Domestic Product) ratio. The higher the value of debt to GDP ratio, the bigger the risk of pay default might be. Thus, the keep increasing price rate bears the risk of worsening domestic economic condition which results in the increasing yield of the government bond in US Dollar.

The result of impulse response function on both YRI10 and YRI30 variables as a consequence of shock on certain variable as much as one standard deviation generally shows the response pattern and direction which tends to be the same even though some have different response quantity and intensity. To find the difference, the test on mean difference of every response until period 12 needs to be checked first.

The shock of one standard deviation of the international interest rate will be negatively responded by the yield of the Government Bond in US Dollar. The yield response for both types of bond has a decreasing trend from the third period to the twelfth period. The difference in effect direction on the cointegration equation (positive effect) and the result of impulse response function (negative effect) is predicted to be the consequence of low-interest rate policy applied by the US Central Bank during the global crisis started in 2008 which is not followed by the decrease in the investment risk rate of the financial market of emerging market countries, thereby causing investors to move the portfolio assets to the safe haven. This movement of portfolio asset will increase the yield of the government Bond in US Dollar. The average difference test result indicates that at significance level $(\alpha=10 \%)$ there is no response difference in each YRI10 and YRI30 variable as the effect of shock in YUS variable. 
Figure 2. The Result of Response Analysis on the Yield of the Government Bond in US Dollar towards Shock of Indonesia Macroeconomic variable and International Interest Rate
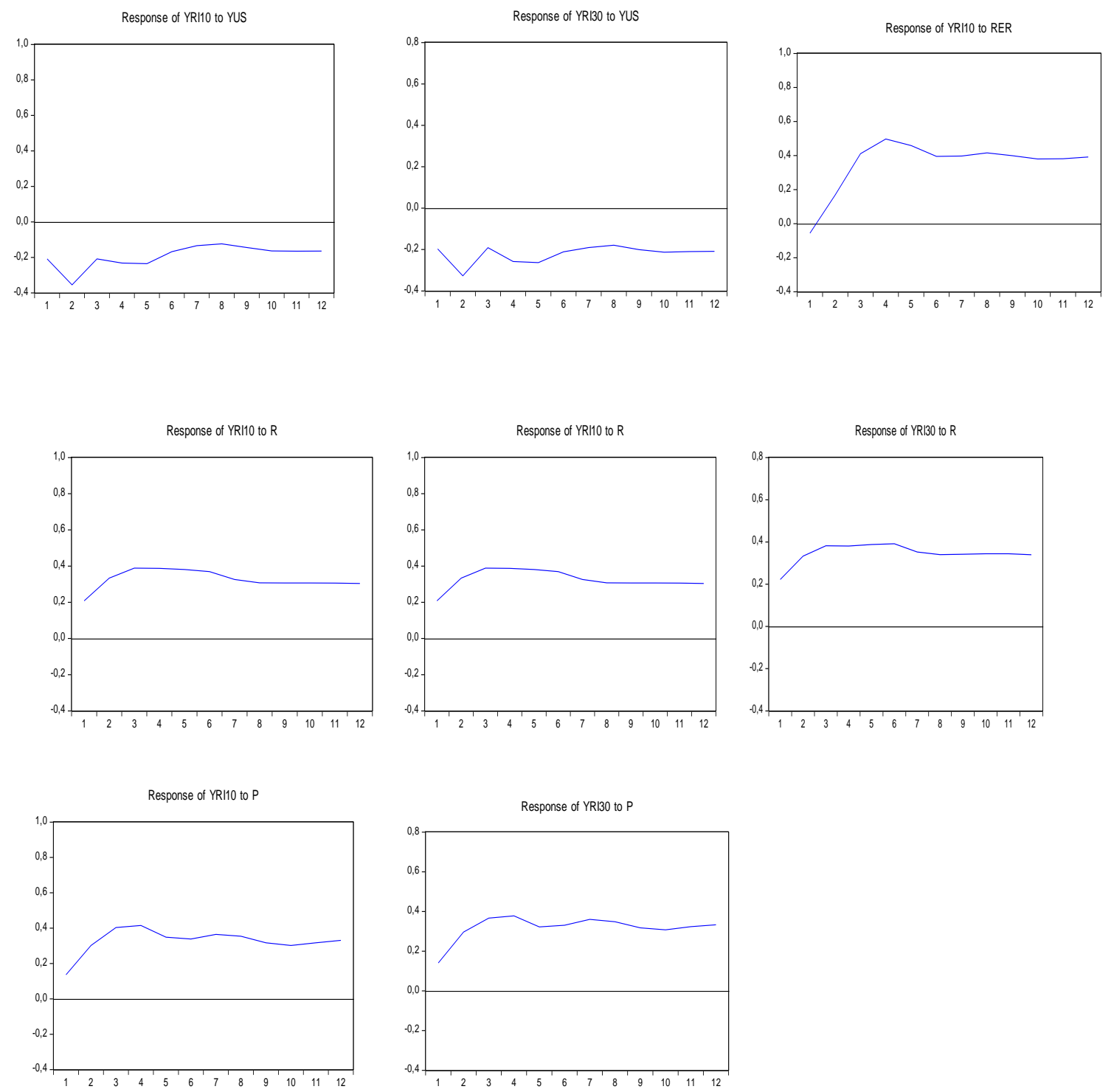

Source: Authors' Calculations

One standard deviation shock of real exchange rate will be negatively responded by the yield of the Government Bond in US Dollar in the first period and will keep decreasing to the positive balance in the second period. This response rises in the third period and reaches its biggest value for both types of yield in the fourth period and then 
experiences a decreasing trend until the twelfth period. Generally, the response of yield of the Government Bond in US Dollar maturing in 10 years is higher than that maturing in 30 years. This different quantity of response is supported by the test result of average difference where statistically, at significance level $(\alpha=10 \%)$, there is a different response in each YRI10 and YRI30 variable as the effect of shock in RER variable.

One standard deviation shock of domestic interest rate will be positively responded by the yielf of the Government Bond in US Dollar. The biggest response of the government bond in US Dollar maturing in 10 years occurs in the third period and gradually declines with less significant quantity up to the twelfth period. Meanwhile, the biggest response of the Government Bond in US Dollar maturing in 30 years happens in the sixth period and gradually decreases with less significant quantity until the twelfth period. The test result of average difference indicates that at significance level $(\alpha=10 \%)$ there is no difference in the response between the yield of the Government Bond in US Dollar maturing in 10 years and that of with 30 year maturity as the consequence of shock in the domestic interest rate.

One standard deviation shock of price rate will be positively responded by the yield of the Government Bond in US Dollar. Next, the yield response for both types of bond experiences a decreasing trend from the fourth period to the twelfth. The test result of average difference demonstrates that at significance level $(\alpha=10 \%)$ there is no difference in response between the yield of the Government Bond maturing in 10 years and that of 30 year maturity as the effect of shock in the price rate.

The testing of average difference from the impulse response function analysis result in each YRI model shows a significant difference between the average response of YRI10 and YRI30 to shock in each variable of Indonesia macroeconomy and international interest rate. The response of the yield of the Government Bond in US Dollar maturing in 10 years to real exchange rate shock is generally bigger than the response as the consequence of other macroeconomic variable shock. In the mean time, the response of the yield of the Government Bond in US Dollar maturing in 30 years to domestic interest rate shock is generally bigger than that of other macroeconomic variable shock. 
Based on the response analysis on the yield of the Government Bond in US Dollar to shock in all Indonesia macroeconomic and international interest rate variables above, it can be concluded that real exchange rate variable shock will get greater response from the yield of the Government Bond in US Dollar maturing in 10 years compared to that of with 30-year maturity. This is expected because the outstanding nominal amount of the Government Bond maturing in 10 years is as much as USD900 millions which is much smaller than the one with 30 year maturity, i.e. USD1,6 millions. The small amount of bond outstanding leads to a low bond liquidity rate and increased risk premium so that the yield developed in the market will be more sensitive to shock. The analysis result of impulse response indicates that the response presence up to the twelfth period which is expected to be affected by factors outside the model which makes the response does not immediately disappear.

Furthermore, variance decomposition analysis can explain innovation in an endogenous variable toward other variables' shock. To find out the difference of contribution domination of a variable on the yield of the Government Bond in US Dollar is by using the test of mean difference of every contribution until period 12 .

\section{Table 2. Result of Variance Decomposition on the yield of the Government Bond in US Dollar maturing in 10 years (in percentage)}

\begin{tabular}{|c|c|c|c|c|c|}
\hline \multirow{2}{*}{ Period } & \multicolumn{6}{|c|}{ Contribution of variable shock to Yield of the Government Bond in US } \\
Dollar maturing in 10 years \\
\cline { 2 - 6 } & YRI30 & YUS & RER & R & P \\
\hline 1 & 86.01560 & 5.595741 & 0.403171 & 5.582649 & 2.402838 \\
\hline 2 & 75.50788 & 8.908490 & 1.659733 & 8.148232 & 5.775669 \\
\hline 3 & 64.79275 & 7.550446 & 7.119658 & 10.86605 & 9.671104 \\
\hline 4 & 57.22820 & 7.054760 & 11.86296 & 12.08332 & 11.77076 \\
\hline 5 & 53.96763 & 6.894441 & 14.10879 & 12.89548 & 12.13365 \\
\hline 6 & 53.11441 & 6.351029 & 14.78148 & 13.39724 & 12.35584 \\
\hline 12 & 50.60462 & 4.899679 & 17.66485 & 13.27519 & 13.55566 \\
\hline
\end{tabular}

Source: Authors' Calculations

Based on table 2 it can be explained that until the second period, the contribution of international interest rate to the yield variation of the Government Bond in US Dollar maturing in 10 years is more dominant than the contribution of each Indonesia macroeconomic variable. Moreover, this contribution of international interest rate experiences a decline in the third period and has the smallest value compared to other 
variables in the twelfth period. In the first period, real exchange rate has the smallest contribution to the yield of the Government Bond in US Dollar maturing in 10 years but starting in the fifth period it has the biggest contribution compared to other economic variables. Contribution of domestic interest rate in the first period has the biggest value compared to other Indonesia macroeconomic variables though it is slightly smaller than the contribution of international interest rate. Meanwhile, the contribution of price rate in the first period is relatively smaller than other variables. Therefore, in a short term (two periods) yield variation of the Government Bond in US Dollar maturing in 10 years is more influenced by international interest rate. As for a longer period, yield variation of the Government Bond in US Dollar with 10 year maturity is more influenced by Indonesia macroeconomic variable with the dominant influence shown by domestic interest rate in the third and fourth period, and real exchange rate from the fifth to the twelfth period.

Table 3. Result of Variance Decomposition on the Yield of the Government Bond in US Dollar maturing in 30 years (in percentage)

\begin{tabular}{|c|c|c|c|c|c|}
\hline \multirow{2}{*}{ Period } & \multicolumn{6}{|c|}{ Contribution of variable shock to Yield of the Government Bond in US } \\
& \multicolumn{5}{|c|}{ Dollar maturing in 30 years } \\
\cline { 2 - 6 } & YRI30 & YUS & RER & R & P \\
\hline 1 & 82.66641 & 5.844293 & 1.028457 & 7.469690 & 2.991153 \\
\hline 2 & 70.24813 & 10.07979 & 1.102917 & 11.11012 & 7.459033 \\
\hline 3 & 60.15929 & 8.714712 & 4.853659 & 14.67371 & 11.59863 \\
\hline 4 & 53.09040 & 8.891497 & 8.058414 & 16.16658 & 13.79310 \\
\hline 5 & 49.99910 & 9.184169 & 9.258903 & 17.41083 & 14.14700 \\
\hline 6 & 49.10610 & 8.759912 & 9.363351 & 18.28301 & 14.48763 \\
\hline 12 & 45.79480 & 7.807133 & 11.10846 & 18.96401 & 16.32558 \\
\hline
\end{tabular}

Source: Authors' Calculations

Based on table 3, it can be explained that the contribution of international interest rate to the yield variation of the Government Bond in US Dollar maturing in 30 years up to the second period is bigger than the contribution of real exchange rate and price rate, but smaller than that of domestic interest rate. Generally, the contribution of real exchange rate is the smallest compared to the contribution of other Indonesia macroeconomic variables. The contribution of domestic interest rate to the yield of the Government Bond in US Dollar maturing in 30 years has an increasing trend and in the 
twelfth period has the biggest value compared to other variables' contributions. Therefore, it can be concluded that the yield variation of the Government Bond in US Dollar maturing in 30 years is more dominantly affected by Indonesia macroeconomic variables with the contribution of domestic interest rate showing the most dominant influence.

\section{CONCLUSION}

Indonesia macroeconomic condition and international interest rate significantly influence the yield of The Government Bond in US Dollar. This result is consistent with the hypothesis where real exchange rate, domestic exchange rate, price rate, and international interest rate positively affect the yield of the Government Bond in US Dollar. Meanwhile, there is a long-term relationship between the condition of Indonesia macroeconomy and the international interest rate toward the yield of the government bond in US Dollar which indicates the presence of correction mechanism where the value of error correction term in both models is negative and significant at $\alpha=5 \%$.

According to the analysis result of impulse response function, both types of yield of the government bond in US Dollar have response pattern which tends to be similar as the effect of shock from each condition of Indonesia macroeconomy and international interest rate. The response of the yield of the government bond in US Dollar maturing in 10 years to real exchange rate is generally bigger than the response due to other macroeconomic variables. Meanwhile, the response of yield of the government bond in US Dollar maturing in 30 years to domestic interest rate shock is generally bigger than the response caused by other macroeconomic variables.

Based on the result of variance decomposition, the contribution of international interest rate to the yield variation of the government bond in US Dollar is relatively dominant in a short run although for the 30-year maturity, the value is slightly lower compared to the contribution of domestic interest rate with decreasing trend of contribution in the long run. In the mean time, in the long run, the contribution of real exchange rate is more dominant to the yield variation of the government bond in US Dollar maturing in 10 years and the contribution of domestic interest rate is more dominant to the yield variation of the Government Bond in US Dollar maturing in 30 
years. The difference in the variable contribution pattern can be an alternative consideration for the government in optimizing debt portfolio.

The limitation of this study is the limited research period so that the analysis process cannot employ a longer lag and many more variables for taking into account the degree of freedom. Limitation in selecting variables also influenced the result of the response on the yield of the government bond in US Dollar which does not immediately disappear due to the effect from other factors beyond the scope of the model.

\section{REFERENCES}

Adli, A. (2013). Analisis Pengaruh Faktor Makroekonomi Terhadap Yield Surat Berharga Negara, Tesis, Program Studi Ilmu Ekonomi, Universitas Indonesia.

Audzeyeva, A. and Schenk-Hoppe, K. R. (2010). The Role of Country, Regional and Global Market Risks in the Dynamics of Latin American Yield Spreads, Journal of International Financial Markets, Institutions, and Money, 20, 404-422.

Bayoumi, T. and Bui, T. (2012). Global Bonding: Do US Bond and Equity Spillovers Dominate Global Financial Markets?," IMF Working Paper, WP/12/298.

Bodie, Z. Kane, A. and Marcus, A. J. (2003). Investments. Fifth edition. McGraw-Hill.

Bredin, D., Hyde, S. and O’Reilly, G. (2010). Monetary Policy Surprises and International Bond Markets, Journal of International Money and Finance, 29, 988-1002.

Budina, N. and Mantchev, T. (2000).Determinants of Bulgarian Brady Bond Prices: An Empirical Assessment, Policy Research Working Paper No. WPS 2277, The World Bank, Washington D.C.

Bunda, I., Hamann, A. J., and Lall, S. (2009). Correlations in emerging market bonds: The role of local and global factors. Emerging markets review, 10(2), 67-96.

Claessens, S., Klingebiel, D., and Schmukler, S. (2003), "Government Bonds in Domestic and Foreign Currency: The Role of Macroeconomic and Institutional Factors," Policy Research Working Paper No. 2986, The World Bank, Washington D.C.

Claudia-Floriana, B. (2008), Determinants of Spreads of Romanian Sovereign Bonds: An Application on The EMBIG Spreads, Dissertation Paper of The Academy of Economic Studies Bucharest.

Enders, W. (1995), Applied Econometric Time Series, John Wiley \& Sons, New York.

Fama, E. F. (1984). Term premiums in bond returns. Journal of Financial Economics, 13(4), 529-546.

Griffin, P. S. (2002), "The Expectations Hypothesis With Non-Negative Rates," Journal of Finance, 6, 265-271.

Gujarati, D. N. (2003), Basic Econometrics, Fourth Edition, McGraw-Hill, Boston. 
Jacobs, P., Abubakar, A., and Siallagan,T. E. (2011), Analisis Perilaku Indikator Debt Market, Buletin Ekonomi Moneter dan Perbankan, Bank Indonesia.

Jeon, B. N., Ji, P., and Zhang, H. (2012), International Linkages of Japanese Bond Markets: An Empirical Analysis, Department of Economics and International Business, Drexel University and Department of Finance and Accounting, Monash University.

Joutz, F. and Maxwell, W. F. (2002), Modelling the Yields on Noninvestment Grade Bond Indexes Credit Risk and Macroeconomic Factors, International Review of Financial Analysis, 11, 345-374.

Juhro, S. (2008), Respon Kebijakan Moneter yang Optimal di Indonesia: The StateContingent Rule?, Buletin Ekonomi Moneter dan Perbankan, Bank Indonesia.

Min, H., Duk-Hee, L,. Nam, C., Park, M,. and Nam, S. (2003), Determinants of EmergingMarket Bond Spreads: Cross-Country Evidence, Global Finance Journal, 14, 271286.

Obstfeld, M. and Rogoff, K.(1996), Foundations of International Macroeconomics, Second Edition, The MIT Press, London.

Tampubolon, G. (2007), Analisis Faktor Determinan yang Mempengaruhi Yield Obligasi: Pendekatan VAR, Tesis, Program Studi Ilmu Ekonomi, Universitas Indonesia. 


\section{Appendix \\ Estimation Result of VECM Model \\ 1. Equation Model YRI10}

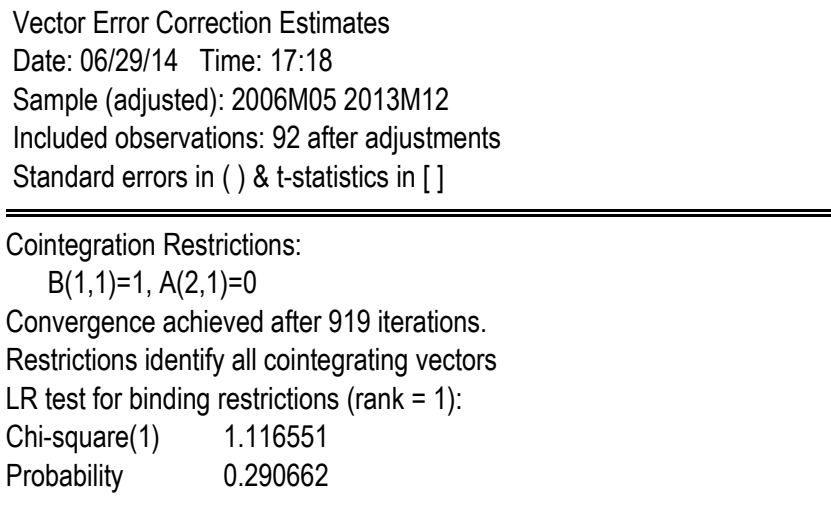

\begin{tabular}{cr}
\hline \hline Cointegrating Eq & CointEq1 \\
\hline \hline YRI10(-1) & 1.000000 \\
YUS(-1) & -12.98381 \\
& $(2.73528)$ \\
& {$[-4.74680]$} \\
RER(-1) & -159.7177 \\
& $(45.6332)$ \\
& {$[-3.50003]$} \\
R(-1) & -11.78406 \\
& $(1.51782)$ \\
& {$[-7.76381]$} \\
P(-1) & -245.2857 \\
& $(50.9309)$ \\
C & {$[-4.81605]$} \\
& 2083.709
\end{tabular}

\begin{tabular}{|c|c|c|c|c|c|c|c|c|}
\hline Error Correction: & $\mathrm{D}(\mathrm{YRI} 10)$ & $D(Y U S)$ & $\mathrm{D}(\mathrm{RER})$ & $D(R)$ & $D(P)$ & \multirow{4}{*}{$\mathrm{D}(\mathrm{R}(-3))$} & {$[-1.68988]$} & {$[-0.52559][0.52526][-0.91142][0.78362]$} \\
\hline & & & & & & & -0.055969 & $0.0075480 .001480-0.0807$ \\
\hline \multirow[t]{3}{*}{ CointEq1 } & -0.021019 & 0.000000 & 0.000355 & 0.057166 & $2.28 \mathrm{E}-05$ & & $(0.04823)$ & (0.00779) (0.00089) (0.07551) (0.00044) \\
\hline & $(0.00612)$ & $(0.00000)$ & $(0.00011)$ & $(0.00986)$ & $(5.7 \mathrm{E}-05)$ & & {$[-1.16038]$} & [0.96912] [ 1.65888] [-1.07006] [0.17754] \\
\hline & {$[-3.43580]$} & {$[\mathrm{NA}]$} & [3.11930] & [5.79995] & [0.40121] & $D(P(-1))$ & 14.68300 & $-0.131726-0.21408545 .07123-0.034533$ \\
\hline \multirow[t]{3}{*}{$\mathrm{D}(\mathrm{YR} / 10(-1))$} & 0.094725 & -0.036587 & -0.013446 & 0.279860 & 0.001235 & & $(13.0371)$ & $(2.10502)(0.24116)(20.4088)(0.11833)$ \\
\hline & $(0.11318)$ & $(0.01828)$ & $(0.00209)$ & $(0.17718)$ & $(0.00103)$ & & {$[1.12625]$} & {$[-0.06258][-0.88774][2.20842][-0.29183]$} \\
\hline & {$[0.83691]$} & {$[-2.00200]$} & {$[-6.42213]$} & [1.57949] & [1.20236] & $D(P(-2))$ & 14.53293 & $-1.155979-0.15104538 .07419-0.242425$ \\
\hline \multirow[t]{3}{*}{$\mathrm{D}(\mathrm{YRI} 10(-2))$} & -0.198889 & -0.042849 & 0.007197 & 0.051944 & 0.000590 & & $(12.7673)$ & $(2.06145)(0.23617)(19.9865)(0.11588)$ \\
\hline & $(0.13069)$ & $(0.02110)$ & $(0.00242)$ & $(0.20459)$ & $(0.00119)$ & & [1.13829] & {$[-0.56076][-0.63957][1.90500][-2.09201]$} \\
\hline & {$[-1.52184]$} & {$[-2.03058]$} & [2.97710] & {$[0.25390]$} & [0.49724] & $D(P(-3))$ & 9.975690 & $-0.085802 \quad 0.25417924 .05035-0.148040$ \\
\hline \multirow[t]{3}{*}{$\mathrm{D}(\mathrm{YRI} 10(-3))$} & -0.023330 & 0.026051 & -0.004927 & 0.361705 & -0.000535 & & $(13.4639)$ & $(2.17393)(0.24905)(21.0770)(0.12220)$ \\
\hline & $(0.14005)$ & $(0.02261)$ & $(0.00259)$ & $(0.21925)$ & $(0.00127)$ & & [0.74092] & {$[-0.03947][1.02058][1.14107][-1.21142]$} \\
\hline & {$[-0.16658]$} & {$[1.15198]$} & {$[-1.90192]$} & [1.64975] & {$[-0.42082]$} & C & -0.364605 & $\begin{array}{llll}-0.023738 & 0.000764 & -0.522634 & 0.007058\end{array}$ \\
\hline \multirow[t]{3}{*}{$\mathrm{D}(\mathrm{YUS}(-1))$} & -1.422499 & 0.539086 & -0.002704 & 0.523391 & -0.002889 & & $(0.16169)$ & $(0.02611)(0.00299)(0.25312)(0.00147)$ \\
\hline & $(0.77093)$ & $(0.12448)$ & $(0.01426)$ & $(1.20685)$ & $(0.00700)$ & & {$[-2.25491]$} & {$[-0.90924][0.25548][-2.06475][4.80941]$} \\
\hline & {$[-1.84517]$} & [4.33080] & {$[-0.18960]$} & [0.43369] & {$[-0.41286]$} & & & \\
\hline \multirow[t]{3}{*}{$\mathrm{D}(\mathrm{YUS}(-2))$} & 0.956219 & -0.082287 & 0.040705 & 2.926449 & 0.005671 & R-squared & 0.304512 & $\begin{array}{llll}0.457766 & 0.601151 & 0.682101 & 0.129157\end{array}$ \\
\hline & $(0.77160)$ & $(0.12459)$ & $(0.01427)$ & $(1.20790)$ & $(0.00700)$ & Adj. R-squared & 0.156141 & $0.3420890 .5160630 .614283-0.056622$ \\
\hline & [1.23927] & {$[-0.66049]$} & {$[2.85$} & {$[2.42277]$} & [0.80975] & Sum sq. resids & 58.12863 & $\begin{array}{llll}1.515442 & 0.019890 & 142.4506 & 0.004789\end{array}$ \\
\hline \multirow[t]{3}{*}{$\mathrm{D}(\mathrm{YUS}(-3))$} & -1.926850 & 0.039873 & $-2.96 \mathrm{E}-05$ & 0.203414 & -0.008387 & S.E. equation & 0.880368 & $\begin{array}{llll}0.142147 & 0.016285 & 1.378166 & 0.007991\end{array}$ \\
\hline & $(0.75997)$ & $(0.12271)$ & $(0.01406)$ & $(1.18969)$ & $(0.00690)$ & F-statistic & 2.052370 & $\begin{array}{llll}3.957287 & 7.065058 & 10.05776 & 0.695217\end{array}$ \\
\hline & {$[-2.53542]$} & {$[0.32494]$} & {$[-0.00210]$} & [0.17098] & {$[-1.21595]$} & Log likelihood & -109.4224 & $58.33741257 .6670-150.6539323 .1689$ \\
\hline \multirow[t]{3}{*}{$D(\operatorname{RER}(-1))$} & 10.50672 & -0.815252 & 0.321415 & -7.627032 & 0.032689 & Akaike AIC & 2.748312 & $-0.898639-5.2318913 .644649-6.655845$ \\
\hline & $(5.69259)$ & $(0.91915)$ & $(0.10530)$ & $(8.91143)$ & $(0.05167)$ & Schwarz SC & 3.214295 & $-0.432657-4.7659084 .110632-6.189862$ \\
\hline & [1.84568] & {$[-0.88697]$} & [3.05236] & {$[-0.85587]$} & [0.63268] & Mean dependent & -0.051780 & $-0.052226-0.001614-0.1868480 .005109$ \\
\hline \multirow[t]{3}{*}{$\mathrm{D}(\mathrm{RER}(-2))$} & 5.327956 & 0.352403 & -0.212043 & 7.855280 & -0.011364 & S.D. dependent & 0.958362 & $\begin{array}{llll}0.175249 & 0.023409 & 2.219050 & 0.007774\end{array}$ \\
\hline & $(5.36557)$ & $(0.86634)$ & & & $(0.04870)$ & & & \\
\hline & [0.99299] & {$[0.40677]$} & {$[-2.13642]$} & {$[0.93521]$} & {$[-0.23315]$} & & & \\
\hline
\end{tabular}




\section{Appendix (continued)}

\section{Equation Model YRI30 \\ Vector Error Correction Estimates}

Date: 06/29/14 Time: 17:26

Sample (adjusted): 2006M05 2013M12

Included observations: 92 after adjustments

Standard errors in ( ) \& t-statistics in [ ]

\section{Cointegration Restrictions: $B(1,1)=1, A(2,1)=0$ \\ Convergence achieved after 248 iterations. \\ Restrictions identify all cointegrating vectors \\ LR test for binding restrictions (rank = 1): \\ Chi-square(1) $\quad 1.393868$ \\ Probability $\quad 0.237753$}

\begin{tabular}{cr}
\hline Cointegrating Eq CointEq1 \\
\hline \hline YRI30(-1) & 1.000000 \\
YUS(-1) & -3.746592 \\
& $(0.83211)$ \\
& {$[-4.50254]$} \\
RER(-1) & -36.07485 \\
& $(13.4738)$ \\
& {$[-2.67741]$} \\
R(-1) & -3.882429 \\
& $(0.46004)$ \\
& {$[-8.43941]$} \\
P(-1) & -74.47471 \\
& $(15.6014)$ \\
C & {$[-4.77358]$} \\
\hline
\end{tabular}

\begin{tabular}{lllll}
\hline \hline Error Correction: $D(Y R I 30)$ & $D(Y U S)$ & $D(R E R)$ & $D(R)$ & $D(P)$ \\
\hline \hline
\end{tabular}

CointEq1 $\quad-0.0665450 .0000000 .0010800 .187245 \quad 6.36 \mathrm{E}-05$ $(0.01809)(0.00000)(0.00036)(0.03123)(0.00018)$ $[-3.67771] \quad[\mathrm{NA}] \quad[3.00716][5.99613][0.35157]$

$\mathrm{D}(\mathrm{YRI} 30(-1)) \quad-0.011975-0.036405-0.0153810 .2507440 .001652$ (0.11172) (0.01955) (0.00221) (0.18710) (0.00109) [-0.10719] [-1.86171] [-6.95706] [ 1.34013] [ 1.51866]

D(YRI30(-2)) $\quad-0.169321-0.0499740 .006097 \quad 0.078962 \quad 0.001106$ (0.13481) (0.02360) (0.00267) (0.22577) (0.00131) [-1.25602] [-2.11792] [ 2.28536] [ 0.34974] [ 0.84284]

$\mathrm{D}(\mathrm{YRI30}(-3)) \quad-0.0557220 .026764-0.0052350 .369280-0.000671$ $(0.14465)(0.02532)(0.00286)(0.24226)(0.00141)$ [-0.38522] [ 1.05709$][-1.82886][1.52434][-0.47629]$

$\mathrm{D}(\mathrm{YUS}(-1)) \quad-1.4322120 .548760-0.004792 \quad 0.628980-0.003040$ $(0.71314)(0.12482)(0.01411)(1.19435)(0.00694)$ [-2.00832] [ 4.39627] [-0.33956] [ 0.52663] [-0.43792]

$\mathrm{D}(\mathrm{YUS}(-2)) \quad 0.850861 \quad-0.0973630 .042375 \quad 2.9000990 .006198$ $(0.71505)(0.12516)(0.01415)(1.19754)(0.00696)$ [ 1.18994] [-0.77793] [ 2.99457] [ 2.42172] [ 0.89048]

D(YUS(-3)) $\quad-1.905083 \quad 0.033115-0.003200 \quad 0.243268-0.009141$ (0.70256) (0.12297) (0.01390) (1.17662) (0.00684) [-2.71164] [0.26929] [-0.23014] [ 0.20675] [-1.33655]

$\mathrm{D}(\operatorname{RER}(-1)) \quad 7.512209-0.895704 \quad 0.332017-6.9967100 .046320$ (5.42252) (0.94913) (0.10731) (9.08148) (0.05278) [ 1.38537] [-0.94371] [ 3.09400] [-0.77044] [0.87752]
$\mathrm{D}(\mathrm{RER}(-3)) \quad 5.496505-0.0527710 .192239-10.60792-0.016828$ (4.10186) (0.71797) (0.08117) (6.86967) (0.03993) [ 1.34000] [-0.07350] [ 2.36822] [-1.54417] [-0.42144]

$D(R(-1)) \quad-0.182008-0.0032640 .002493-0.1381220 .000133$ $(0.06734)(0.01179)(0.00133)(0.11278)(0.00066)$ [-2.70281] [-0.27694] [ 1.87070] [-1.22471] [0.20320]

$D(R(-2)) \quad-0.103890-0.0054350 .000692-0.0636830 .000396$ $(0.05762)(0.01009)(0.00114)(0.09650)(0.00056)$ [-1.80298] [-0.53889] [0.60707] [-0.65991] [ 0.70551]

$\mathrm{D}(\mathrm{R}(-3)) \quad-0.061125 \quad 0.007336 \quad 0.001575 \quad-0.066200 \quad 7.58 \mathrm{E}-05$ $(0.04515)(0.00790)(0.00089)(0.07561)(0.00044)$ [-1.35394] [0.92834] [ 1.76257] [-0.87556] [0.17255]

$\mathrm{D}(\mathrm{P}(-1)) \quad 16.52770 \quad 0.028163-0.21117242 .36544-0.049988$ (12.2024) (2.13584) (0.24148) (20.4362) (0.11878) [ 1.35446] [ 0.01319] [-0.87448] [ 2.07306] [-0.42083]

$\mathrm{D}(\mathrm{P}(-2)) \quad 12.40460-1.237418-0.10810235 .44610-0.245094$ (11.9749) (2.09602) (0.23698) (20.0552) (0.11657) [ 1.03588] [-0.59037] [-0.45617] [ 1.76742] [-2.10258]

$\mathrm{D}(\mathrm{P}(-3)) \quad 9.887135-0.159610 \quad 0.222612 \quad 24.13758-0.150248$ (12.4601) (2.18095) (0.24658) (20.8679) (0.12129) [0.79350] [-0.07318] [0.90279] [ 1.15668] [-1.23873]

C $\quad-0.328317-0.0224170 .000911-0.5119710 .007106$ $(0.14942)(0.02615)(0.00296)(0.25024)(0.00145)$ [-2.19733] [-0.85716] [0.30818] [-2.04593] [ 4.88536]

$\begin{array}{lllllll}\text { R-squared } & 0.266692 & 0.454502 & 0.609200 & 0.688517 & 0.142491\end{array}$ $\begin{array}{llllll}\text { Adj. R-squared } 0.110253 & 0.338129 & 0.525829 & 0.622067 & -0.040445\end{array}$ $\begin{array}{llllll}\text { Sum sq. resids } 49.76217 & 1.524563 & 0.019488 & 139.5759 & 0.004715\end{array}$ $\begin{array}{lllllll}\text { S.E. equation } & 0.814552 & 0.142575 & 0.016120 & 1.364189 & 0.007929\end{array}$

$\begin{array}{lllllll}\text { F-statistic } & 1.704770 & 3.905568 & 7.307118 & 10.36146 & 0.778913\end{array}$ Log likelihood -102.2738 $58.06138 \quad 258.6048$-149.7160 323.8786 Akaike AIC $2.592909-0.892639-5.252278 \quad 3.624262-6.671274$

Schwarz SC $3.058892-0.426656-4.7862954 .090245-6.205292$ Mean depender $-0.011272-0.052226-0.001614-0.1868480 .005109$ S.D. dependent $0.863547 \quad 0.1752490 .0234092 .2190500 .007774$ 